\title{
Reinventing the tree: Reflections on the organic growth and creative pruning of fisheries management structures
}

\author{
Nigel Haggan
}

\section{ABSTRACT}

Fisheries management is seen as the result of a process of organic growth and accretion driven by the realization that human ingenuity has outstripped the productive capacity of fisheries. The evolution of the symbiotic scientific and management communities is traced from an expansionist period in the 1950s and 1960s to today's climate of depletion. Stakeholder trust in the quality of the information that underpins management decisions, and a guarantee of continuing benefits, are proposed as the key elements of sustainability. Inclusivity, perspective and clarity are identified as key contributors to the perception of fairness, which alone can ensure that fishers comply with management systems. The role of fishing communities, science, government, the public and other interests in policy making is discussed. The reinvention of fisheries management cannot be entrusted to a new partnership, however comprehensive, among those directly involved in fisheries. Fish and fisheries must somehow capture the support of the general public, to whom political decision makers respond. The preservation of fisheries values must become a vital consideration for industry. One way to approach this is to stop dead fish and start selling fish as a metaphor for the quality of life. Ecosystem approaches, interdisciplinary cooperation. Dialogue with fishers and fishing communities and the incorporation of local ecological knowledge, may yet enable fisheries management to haul itself out of the water like Darwin's fish and peer blearily at the fresh environment. The next evolutionary challenge is to integrate human communities into the model as more than just a component of fishing mortality.

\subsection{INTRODUCTION}

This chapter takes a slightly irreverent look at the notion of 'reinventing' fisheries management. It argues that fisheries management never was invented; it simply grew like a tree as the realization dawned that human intervention could drive fish stocks to extinction. The first shoot on Canada's west coast sprang with declining salmon catch. It has since sprouted almost as many roots and branches as there are stocks and species, and even more when stock assessment, management, habitat and enforcement are treated separately by organisations such as Canada's Department of Fisheries and Oceans (DFO).

The 'trees' of Europe are much, much older. Indeed, there is a small, but vocal group which claims that the Canadian tree is a European transplant. Seeds from this ancient stock are now sprouting throughout the developing world. Whether to continue to fertilize with Western science, uproot in favour of local varieties or cross-pollinate is a subject of lively debate. As evidenced by any established church, or indeed, university, institutions are much more resistant to change than the people who created them back in the mists of time. Laws, regulations and beliefs accrete over time like oxides and marine organisms on an ancient shipwreck. In Canada, bilateral consultative processes have now started to accrete at an explosive rate. Our collective ability to 'reinvent' fisheries management hinges on retaining elements of value while 
deconstructing existing management structures and integrating them into new approaches and tools.

\section{The age of innocence}

'There are plenty of fish in the sea.' Oral history abounds with tales of abundance. The Hanseatic League, a vast Middle Ages trading empire, was founded on the amazing productivity of the Baltic Sea herring (Cushing 1988). Old people in Ireland and Elders of British Columbia (BC) First Nations alike, tell of crossing rivers dryshod on the backs of returning salmon. There was little need for management in those early days because marine productivity was far in excess of catching capacity. Early government documents on the BC fishery do little more than marvel at the abundance, suggest ways to exploit it and present figures on annual catch (Canada 1903). Ironically, in view of their later exclusion, an earlier document (BC 1875) recommends that 'Indians' take the lead in the commercial fishery.

\section{A good time for scientists}

The growth of local and world markets for fish led to rapid and significant improvements in catching and processing ability. Newell (1988; 1990) describes this process in the development of the BC fishery. Newell (1993) also provides a good account of the impact of modern industrial and fisheries legislation on the Aboriginal fishery. Meryl Williams (Chapter 11, this volume) characterizes this as a time when fisheries scientists were naturalists. They spent their time identifying species and examining life cycle stages. Above all, they worked with fishers. They went out on fishing vessels exploring new grounds, developing fish-finders, testing and developing new gear. Scientists were welcome aboard. A good time was had by all. Government agencies virtually threw subsidies and low-interest loans at fishers and processors. Vessels grew in size and power. Fishing became increasingly lucrative.

\section{The age of experience}

Powerful vessels, sophisticated fish-finding and catching gear and onboard processing allowed fishing at great distances and in weather and sea conditions that would have tied up earlier fleets. Fish were found and hunted throughout their range. Walters and Pearse (1996) cite access to offshore spawning aggregations through new technology as a major causative factor of stock collapse. BC abalone were abundant until the 1970s when the subtidal population was opened to a dive fishery. In a few years, spawning biomass was reduced to a point where the entire fishery. Including the Aboriginal component; was closed (Parsons 1993). North Sea plaice stocks, which had recovered during World War II, were fished down. To counter this, a juvenile rearing area or 'plaice box' was set aside off the Dutch coast (Rijnsdorp and Millner 1996). What this failed to do was to protect adults. As Walters and Maguire (1996) note regarding the northern cod collapse in Atlantic Canada, natural or established refugia are a key component of sustainability. It is clear that these refugia must exist both for adults and for juveniles.

Increasing pressures on fish stocks between the 1970s and early 1990s mark the time when the 'naturalist' was upstaged by the statistician and stock modeller. Computer models, stock assessment, harvest rates and quota setting became the order of the day. In recent years, the mathematical approach has come into question. The collapse of the northern cod and the masking of declines in real abundance by stable or increasing CPUE (catch per unit effort) and 
incorrect estimates of average age, as in the Pacific Ocean perch fishery (Richards and Schnute, Chapter 30, this volume), are significant factors in this falling off among the faithful. Walters and Pearse (1996) and Walters and Maguire (1996) provide a good account of the problems which arise when fixed quotas or harvest rates are based on inadequate or flawed information on what is happening under the surface. The lack of accountability which allows political pressures to override such scientific advice as does exist is also a significant factor. Walters (1995) discusses these pressures at length.

\section{Community outrage and political heat}

One important effect of a major stock collapse is to bring fisheries management and science into disrepute. This is most obvious amongst those fishing communities (local or gear-type) that are affected. The community outrage provoked by loss of livelihood and lifestyle has prompted a move to get social scientists to clean up the mess left by biologists, economists and mathematicians. This chore is rejected by some social scientists, who feel strongly that fisheries scientists have not reciprocated their effort to learn the language and tools of fisheries science. Jentoft, Chapter 12, this volume and Maguire, Chapter 18, this volume, also take a strong position on involving communities in the dialogue. It is less clear, at least to this writer, how one group of scientists learning another's secret language will contribute to grassroots understanding of fisheries management.

To summarize. Over the last 30 years, many of the world's great fisheries have gone from abundance to depletion. Over the same period, fisheries science has cycled from the 'generalist' approach of Meryl Williams' naturalist, through a long affair with economics and mathematics, to today's tendency to look to social scientists and fishing communities for answers. Ironically, a bad time for fish is now a good time for social scientists, at least in terms of research funding.

\section{Pruning the tree}

Stock depletion affects the livelihood and lifestyle of communities. Equally importantly, it reduces or negates returns to the country as a whole. Mitigating community impact from the northern cod collapse has cost Canada at least \$3 billion to date (Canada 1997). Science and management are most needed when stocks are depleted or endangered. Today, however, many governments are in a lean, tight-fisted mode compared with the expansionist times of the 1960s and 1970s. The days are over when bad news for fish was good news for the fisheries science budget. This vicious cycle, where depletion demands more management and a greater need for science at a time when financial returns are down, is a major consideration for policy makers and scientists.

\subsection{FACTORS AFFECTING SUSTAINABILITY}

As industry, government and science struggle with the transition from abundance to scarcity, the main forces working against sustainability are:

- lack of information;

- declining benefits and rising costs. 
These factors lead inevitably to a breakdown in voluntary compliance. Agreement on conservation and management is unlikely in the absence of quality information. Lack of trust in the source of the information sabotages any chance of broadly based agreement. No agreement will hold when benefits decline and costs rise.

\section{Lack of information}

Without information on fish stocks and habitat, there can be no credible management planning. There can be no credible assessment of negative impact by competing human activity. If there is no baseline information on stock strength and habitat quality, there is no yardstick to maintain environmental standards or to protect the quality and quantity of water on which all life depends.

At least in $\mathrm{BC}$, failure to implement a transition phase from rigid government control to cooperative management between government and stakeholders is by far the most immediate threat to sustainable fisheries. Failure to maintain data-gathering capability and confidence in the data is a major roadblock to voluntary compliance among historic and emerging stakeholders. The irony is that much of the information needed to manage any fishery does exist. The problem is that it is compartmentalized in the realm of science, in the databases of government agencies and in the heads and logs of fishers. The integration of local ecological knowledge and mainstream science is one of the major challenges of a new science and practice of fisheries management.

\section{Managing the rate of decline}

Pauly (1995) observes that fisheries scientists tend to view the productive potential of a stock as the amount of fish when they started out their scientific career. The perception of productive capacity thus 'ratchets down' with successive generations. This concept is well understood by BC's Aboriginal peoples, whose rich cultures and economic wealth were founded and sustained by abundant fisheries resources. As Percy Walkus of the Oweekeno Nation observed in a 1992 meeting with DFO at which the writer was present, "All that DFO are doing is managing the rate of decline."

\section{Take the money and run}

The perception that stocks are unlikely to recover, coupled with a lack of political will to face up to the costs of rebuilding, makes it likely that the last of a depleted stock will be 'mined out.' The problem is particularly acute when large sections of a fishery are owned by diversified corporations whose 'stake' in the fishery may well be modest compared with their other business interests. The temptation to catch the last fish and reinvest money in other, unrelated areas is enormous. The larger problem that many fish stocks provide a lower annual rate of return than other business investment is also an incentive to 'mine them out' and invest the proceeds elsewhere.

\section{Breakdown in the perception of fairness}

The commercial sector has been the only significant player in the recent history of the BC salmon fishery. Traditional Aboriginal fisheries were legislated out of existence (Newell 1993). The sport sector had not emerged as a significant player in the allocation stakes. There was no 
'public interest' separate from government for environmentalists to claim as a constituency. The system worked. not so much because DFO had enough of a police presence, as because industry. the de facto sole client, self-policed because they perceived the system as fair and equitable to them. To illustrate this, Pearse and Larkin (1992) cite DFO's catch breakdown for the preceding 5 years as $92.3 \%$ commercial, with Aboriginal and sport fisheries at 3.4\% each.

The perception of fairness in the BC salmon fishery has broken down within the last decade. The problem of diminishing returns is exacerbated by friction between Canada and the US over interpretation of the 1985 Pacific Salmon Treaty; allocation issues between the three commercial gear types of seiners, gill netters and trollers, increasing allocation to the sportfishing industry; and the re-emergence. through the 1982 Constitution Act (Canada 1982), the 1990 Sparrow decision of the Supreme Court of Canada (Canada 1990) and the new Treaty process (BC Claims Task Force 1991), of a significant, but as yet unquantified, Aboriginal interest in the fishery. The drive to redress past social injustice in South Africa by re-allocating fisheries provides an interesting correlative to the re-emergence of First Nations in the BC fishery (Cochrane and Payne, Chapter 5, this volume). It is evident that, without the perception of fairness, there is little hope that fishers will police themselves.

\subsection{TOWARDS SUSTAINABLE FISHERIES MANAGEMENT}

\section{Reaching for a common vision}

People need security of benefits if they are to work together for any length of time (Scott, Chapter 15; Hart, Chapter 17; Hart and Pitcher, Chapter 16; all in this volume). When stock levels are low, resource rebuilding holds out the best hope because most fish stocks recover much faster than other natural resources such as trees, not to mention oil reserves and ore bodies. The notion of 'primal abundance' (Pitcher and Pauly, Chapter 24, this volume) provides some hope of escape from squabbling over the crumbs on today's allocation table. Success in defining stock production levels before modern industrial fishing began, could provide a common vision. To argue that this is not achievable misses the point that a vision is something worth striving for, something to keep in mind when the going gets tough.

The trick for the players in any fishery is to agree on process and achievable steps. The process and steps cannot ignore the 'politician's dilemma' of balancing long-term conservation against the immediate needs of voters and/or powerful interests. If fisheries management cannot become workable, affordable and acceptable, the late Peter Larkin's axiom 'you can't get there from here' will be its epitaph (Larkin 1979). As a first step toward policies tor sustainable fisheries, two deceptively simple questions can be posed. First, what are the elements of a sustainable fishery? Second, who are the players who need to be involved in policy making?

\section{What are the elements of a sustainable fishery?}

While it is neither possible nor desirable to create a rigid fonnula for the world's fisheries, the following criteria are put forward for consideration:

- a whole-ecosystem approach to fish, fishers and environment;

- understanding and maintaining biodiversity;

- maintaining aquatic ecosystems at their full productive potential; 
- a continuing flow of high-quality benefits to stakeholders;

- public awareness of the nature of the resource and flow of benefits;

- harmonization with 'competing' resource sectors;

- clear understanding of macroeconomic and other external factors,

\section{Who should participate in policy development?}

Until recently, policy making has been a prerogative of central government .The fleet expansion/stock depletion cycle was spawned by deliberate government policies. New policies must speak to the hearts and minds of consumptive and non-consumptive interests. The bare essentials of policy making are inclusivity, perspective and clarity. The previous list of criteria gives some indication of the players who need to be at the policy table. Inclusivity is also the best assurance that all the necessary perspectives will be available. Inclusivity, perspective and clarity are also important contributors to the perception of fairness.

\section{Inclusivity}

Fisheries policy decisions involve people, fish and the environment. People can represent themselves. The question of who speaks for fish and environment is much thornier. The old answer was government, but questions persist about the relationship between government and industry. Trade-offs between different resource sectors and other countries are also an issue. Another answer is by one or more of the organizations who have appointed themselves as the conscience of the environment. Not everyone is happy with that. Yet another answer is by the fishers themselves: after all, who has most to lose? In the absence of consensus, the developed world has reverted to the animal trials of mediaeval Europe (where, for example, rats could be hauled into court for damaging a grain crop). The US Endangered Species Act and the spotted owl is a case in point. There are two problems with this. Courts are a 'win or lose' option. Court decisions are also pitifully short on direction or resources for implementation. The principle of inclusivity seeks to transcend the bilateral or dualistic processes that have dogged fisheries management-people vs fish, one gear type vs another, logging $v$ s fishing, environment $v s$ people, and so forth. The principle of inclusivity requires, if not the presence, then at least the input of every interest, whether consumptive or non-consumptive. No doubt this will create cumbersome bodies and tedious processes, but is this any worse than isolated lobbies competing for public support and access to decision makers?

\section{Perspective}

The principle of inclusivity provides the best guarantee that considerations such as the public interest, macroeconomic factors and competing resource industry are taken into account. These larger perspectives provide essential context for the more 'local' perspectives of biology. mathematics, social science and the local knowledge of fishers and their communities. Each perspective, whether broad or narrow, can be seen as a lens. The challenge in any particular fishery is to ascertain that all the lenses are present before trying to get the right focus. This will require the participation of skilled facilitators and mediators, at least until the participants get to know and understand each other.

\section{Clarity}


If you cross a bureaucrat with a scientist you get a policy you can't understand. Good policy speaks directly to the hearts and minds of those for whom it is designed. The goal is clear statements in simple terms, illustrated, where possible, by relevant examples. The secret languages of science are virtually impenetrable, even between disciplines. The principle of clarity requires the translation of these secret languages. This demystification need not trivialize science, nor talk down to fishers and their communities. It is rather a broadening of the scope of science to include nontraditional data sources and the intuition of those who live by the water.

\section{Workability - the perception of fairness}

While inclusivity satisfies some of the perception of fairness, it does not guarantee voluntary compliance amongst fishers. 'Cops and robbers' systems do not work without the will to comply. As a simple example, it is the consensus amongst drivers, pedestrians and cyclists to obey a set of rules that keeps us alive on the roads of the world, not the number of police. Voluntary compliance can exist only in a system that is perceived to be fair. Although fairness is essentially subjective, there can be no doubt that stakeholder participation in the design and delivery of a management regime is a vital contributor. The following elements can be identified:

- stakeholder participation in system design;

- agreement on cost-sharing formulas for management and where necessary.rebuilding;

- $\quad$ stakeholder participation in information gathering and analysis;

- $\quad$ assurance that the system provides the best guarantee of sustainable benefits;

- a system for ensuring a fair distribution of benefits.

\section{Affordability}

One key to affordability is to transfer the responsibility for data collection from government to the fishing community. They know where the fish are. They know the local conditions. They have better boats. Above all, there are more of them. The best of all arguments is that fishers will put faith in data they have a hand in collecting. This should not let government off the hook. Profitable fisheries generate downstream employment and new wealth for the nation. Government plays a role in generating economic development and has a responsibility to reinvest revenue from taxes paid by fishers in the resource. Government also has a responsibility where stocks and/or habitat have been affected by external activity. That said, the relative contributions need to be defined. As a bare minimum, government has a responsibility to lead or participate in the design of science and to audit the results of management.

'When you open a can of worms, the only way to recan it is to use a bigger can' (Caesar, De Bello Gallico). This thought prompted Julius Caesar to create the Roman Empire, if not the largest, then at least one of the most durable cans in human history. The Roman Empire is relevant to the reinvention of fisheries management in that it brought diverse elements under one law.

The Roman Empire differs from late 20th century fisheries management in one important respect. Caesar is dead. The late 20th century emphasizes horizontal processes such as collaboration, partnership and community empowerment. The very nature of fish and the water in which they live demands an extraordinary level of dialogue and collaboration between resource users. As an example, BC salmon management involves the logging, mining and power generation industries, farmers, urban development, commercial, sport and Aboriginal users and 
interaction with the US and other Pacific Rim countries. Although the Pacific salmon is a valuable resource, it pales into insignificance when compared with several of the above-noted sectors.

The reinvention of fisheries management cannot therefore be entrusted to a new partnership, however comprehensive, between those directly involved in fisheries. Fish and fisheries must somehow capture the support of the general public to whom political decision makers respond. The preservation of fisheries values must become a vital consideration for 'competing industry'. One way to approach this is to stop selling dead fish and start selling fish as a metaphor for the quality of life.

Marine protected areas can play an important part in raising human awareness of fisheries values (Christensen and Pauly 1992)(Sumaila, Chapter 23, this volume), Ecopath \{ $\{139$ Christensen, V. $1992\}\}$ and Ecosim (Walters et al. 1997) are important steps towards understanding whole ecosystems. Equally importantly, they are a bridge to local environmental knowledge (Haggan 1996). Ecosystem approaches, interdisciplinary cooperation, dialogue with fishers and fishing communities and the incorporation of local ecological knowledge, may yet enable fisheries management to haul itself out of the water like Darwin's fish and peer blearily at the fresh environment. The next evolutionary challenge is to integrate human communities into the model as more than just a component of fishing mortality.

\section{ACKNOWLEDGEMENTS}

I would like to thank Tony Pitcher for encouragement and critical comments, Daniel Pauly for showing me the potential for ecosystem modelling, Ron MacLeod for sharing his insights into BC fisheries management, Percy Walkus and other BC First Nation members for their patience and instruction. Likewise my wife Pam Brown of the Heiltsuk Nation for her patience and incisive comment. Any errors or omissions are of course my own.

\section{REFERENCES}

BC (1875) Report of the Government of British Columbia on the Subject of Indian Reserves. Report of a Committee of the Honourable the Executive Council, approved by His Honour the Lieutenant Governor on the 18th Day of August, 1875.Papers connected with the Indian land question, 1850-1875. Printed by R. Wolfenden, Victoria.

BC Claims Task Force. (1991) Report of the British Columbia Claims Task Force.. BC Claims Task Force, Vancouver, BC. 84p.

Canada. (1997) Report of the Auditor-General on Fisheries and Oceans Canada-Sustainable Fisheries Framework: Atlantic Groundfish. URL: http://www.oagbvg.gc.ca/internet/English/parl_oag_199710_14_e_8095.html, Accessed 6/9/2011, 2011.

Canada. (1990) Regina v. Sparrow, 1 Supreme Court Registry. 1075.

Canada. (1982) Constitution Act. Enacted by the Canada Act, 1982.

Canada. (1903) Thirty-Fifth Annual Report of the Department of Marine and Fisheries, 1902. Printed by Order of Parliament. Sessional Paper No. 22: S. E. Dawson, Printer to the King's Most Excellent Majesty, Ottawa. http://www.dfo-mpo.gc.ca/Library/199732-1902.pdf.

Christensen, V. and Pauly, D. (1992) ECOPATH II - A system for balancing steady-state ecosystem models and calculating network characteristics. Ecological Modeling, 61: 169185. 
Cushing, D.H. (1988) The provident sea. Cambridge University Press, Cambridge Cambridgeshire ; New York, 329p.

Haggan, N. (1996) Integration of traditional knowledge. Pages 88 in: Mass-balance models of NE Pacific ecosystems. Pauly, D. and Christensen, V. (eds). Fisheries Centre Research Reports 4(1).

Larkin, P.A. (1979) Maybe you can't get there from here: a foreshortened history of research in relation to management of Pacific salmon. Journal of the Fisheries Research Board of Canada, 36: 98-106.

Newell, D. (1990) The Development of the Pacific salmon-canning industry: a grown man's game. McGill Queens University Press, 336p.

Newell, D. (1988) Dispersal and concentration: the slowly changing spatial pattern of the British Columbia salmon canning industry. Journal of Historical Geography, 14(1): 22-36.

Newell, D. (1993) Tangled webs of history: Indians and the law in Canada's Pacific Coast Fisheries. University of Toronto, 306p.

Parsons, L. (1993) Management of marine fisheries in Canada. National Research.

Pauly, D. (1995) Anecdotes and the shifting baseline syndrome of fisheries. Trends in Ecology and Evolution, 10: 430.

Pearse, P.H. and Larkin, P. (1992) Managing Salmon in the Fraser. Report to the Minister of Fisheries and Oceans on the Fraser River Salmon Investigation. Department of Fisheries and Oceans, Vancouver. 36p.

Rijnsdorp, A.D. and Millner, R.S. (1996) Trends in population dynamics and exploitation of North Sea plaice (Pleuronectes platessa L.) since the late 1800s. ICES Journal of Marine Science, 53(6): 1170.

Walters, C. (1995) Fish on the line: the future of Pacific fisheries.

Walters, C. and Maguire, J.J. (1996) Lessons for stock assessment from the northern cod collapse. Reviews in Fish Biology and Fisheries, 6(2): 125-137.

Walters, C. and Pearse, P.H. (1996) Stock information requirements for quota management systems in commercial fisheries. Reviews in Fish Biology and Fisheries, 6(1): 21-42.

Walters, C.J., Christensen, V. and Pauly, D. (1997) Structuring dynamic models of exploited ecosystems from trophic mass-balance assessments. Reviews in Fish Biology and Fisheries, 7: 139-172. 